Vol. 5, n`2 | 2001

Varia

\title{
German Police History Since 1990. A Participant Observers's Report
}

Herbert Reinke

\section{(2) OpenEdition \\ Journals}

Electronic version

URL: https://journals.openedition.org/chs/769

DOI: $10.4000 /$ chs.769

ISSN: 1663-4837

Publisher

Librairie Droz

Printed version

Date of publication: 1 January 2001

Number of pages: 182-183

ISBN: 2-600-00664-8

ISSN: 1422-0857

\section{Electronic reference}

Herbert Reinke, "German Police History Since 1990. A Participant Observers's Report", Crime, Histoire \& Sociétés / Crime, History \& Societies [Online], Vol. 5, n² | 2001, Online since 02 April 2009, connection on 25 March 2022. URL: http://journals.openedition.org/chs/769 ; DOI: https://doi.org/10.4000/chs. 769 


\title{
German Police History Since 1990 A Participant Observers's Report
}

\author{
Herbert Reinke
}

Until the beginning of the 1990s, only few German-speaking historians and social scientists took an interest in police development and history. Before that time, police history in Germany had taken place more or less in the writings of scholars from law history and in the memoirs of former policemen only. In 1990, Alf Lüdtke convinced the German Historical Association to include a session on police history in the program of the Associations Annual Meeting, which took place that year at the University of Bochum. This session had a significant effect: It became the starting point for a loosely woven network of German-speaking historians, sociologists, political scientists, and criminologists, interested in police development and history, and it became the first meeting of an - since then - ongoing series of workshops and conferences on police history, which - since 1991 - under the title Kolloquium zur Polizeigeschichte were carried out annually at the first weekend of July. This year (2001), the police history workshop took place at the University of Erfurt, organized and directed by Alf Lüdtke and Herbert Reinke. The police history conference will probably go abroad next year: The University of Twente (Enschede, The Netherlands), where a major Dutch police history project is located, will probably host the Kolloquium zur Polizeigeschichte in 2002.

The following list gives the themes/headlines, the names of the respective organizers and the locations of the conference since 1990.

1. 1990: Sicherheit und Wohlfahrt. Polizeiliches Handeln vom Vorkonstitualismus bis zur Weimarer Republik - Security and Welfare (Bochum, Alf Lüdtke)

2. 1991: Polizei und Wohlfahrt - Police and Welfare (Liestal/Basel - Switzerland, Martin Leuenberger)

3. 1992: Polizei und Formwandel von Herrschaft in der bürgerlichen Gesellschaft - Police and Bourgeois Class Society (Köln, Herbert Reinke)

4. 1993: Polizei als bürokratische Organisation - Police as Bureaucratic Organization (Berlin, Ralph Jessen)

5. 1994: Polizeigeschichte in zwei Diktaturen - Police History under two Dictatorships (Hamburg, Michael Wildt)

6. 1995: (Selbst-) Bilder der Polizei - (Self-) Images of the Police (Augsburg, Gerhard Fürmetz) 
7. 1996: Polizeiliche Texte-Gesellschaftliche Kontexte und Kriminalität-Police Texts, Societal Contexts and Criminality (Münster, Herbert Reinke \& Peter Nitschke)

8.1997: Denunziation oder Kooperation? Formen der Zusammenarbeit von Polizei und Publikum, 18. bis 20.Jahrhundert - Denunciation or Cooperation? Police and Public from the $18^{\text {th }}$ to the $20^{\text {th }}$ Century (Göttingen, Alf Lüdtke \& Gerhard Fürmetz)

9.1998: Polizei: Orte und Bewegung im Raum - The Police: Places and Movements in Space (Berlin, Claudia Ulbrich \& Martina Hohkamp)

10. 1999: Polizei und Technik - Police and Technique (Hamburg, Klaus Weinhauer)

11.2000: Selbstverständnis und Erinnerungsdiskurse in der Polizei - The Police and its Past: (Münster, Alfons Kenkmann \& Christoph Spieker)

12. 2001: Polizei und Gewalt - Police and Force (Erfurt, Alf Lüdtke \& Herbert Reinke)

The $13^{\text {th }}$ Kolloquium fuir Polizeigeschichte will be organised in cooperation with the University of Twente (Enschede, The Netherlands). The conference will be prepared and directed by Guus Meershoek, Cyrille Fijnaut and other Dutch colleagues, involved in a major project on the Dutch police in the $19^{\text {th }}$ and $20^{\text {th }}$ centuries.

For further information on the colloquia nos. 1-12 (titles of the papers given etc.) and for a selective bibliography of the members of the police history group, please contact: www.uni-wuppertal.de/FB 1/reinke. 